\title{
Colonisation and community structure of benthic diatoms on artificial substrates following a major flood event: A case of the Kowie River (Eastern Cape, South Africa)
}

\author{
Tatenda Dalu*, P William Froneman', Lenin D Chari' and Nicole B Richoux ${ }^{1}$ \\ 'Zoology and Entomology, Rhodes University, P O Box 94, Grahamstown 6140, South Africa
}

\begin{abstract}
A major flooding event that occurred during October-November 2012 caused major changes in the Kowie River hydromorphology and aquatic communities. The aim of our study was to identify the environmental variables that structure riverine benthic diatom communities at upstream and downstream locations $25 \mathrm{~km}$ apart on the Kowie River, South Africa. This was undertaken using tiles as artificial substrates so that we could study how the communities developed after the flood disturbance. The diatom community structure was assessed over a 28-day period following a flood event in October 2012. The Mann Whitney test indicated that there was a statistically significant difference $(p<0.05)$ in total dissolved solids, salinity, $\mathrm{pH}$ and oxygen reduction potential between the two sites. In total, 58 diatom species belonging to 30 genera were identified over the 28-day study. Achnanthidium minutissimum, Fragilaria biceps, F. ulna var. acus, Pinnularia borealis and P. acrosphaeria were the most numerically dominant on Day 7 and were considered as early colonisers, while on Day 28, Achnathidium minutissimum, F. capucina, Craticula buderi, C. vixnegligenda, Diploneis subovalis and Gomphonema venusta, the late colonisers, were dominant. The species richness increased from 13 (upstream location) on Day 7 to 22 (both locations) by Day 21. A redundancy analysis showed that total suspended solids, salinity, resistivity, $\mathrm{pH}$ and oxygen reduction potential were the most significant physico-chemical variables explaining diatom composition. The results from this relatively smallscale tile experiment indicate the complexity of freshwater benthic diatom community structure and development.
\end{abstract}

Keywords: water flow, total dissolved solids, Fragilaria sp., tile substrate, resistivity

\section{INTRODUCTION}

Numerous studies have been conducted on the seasonal dynamics of diatom communities in lotic and lentic ecosystems (Ruth, 1977; Gamier et al., 1995; Ha et al., 1998; Lane 2003; Claquin et al., 2006; Wojtal and Sobczyk, 2012), with diatom community structure periodicity being largely described more in lentic than lotic systems (Gamier et al., 1995; Claquin et al., 2006). Stream diatom communities are composed primarily of benthic and epiphytic species, whilst planktonic genera are less prevalent owing to their displacement by water currents which disrupt their population growth and development (Ruth, 1977; Claquin et al., 2006). Although benthic diatoms are dominant contributors to primary production in rivers and streams (Claquin et al., 2006) and are an important food source for many invertebrates (Lane, 2003), we know surprisingly little about their community structure and dynamics. Moreover, diatoms are important biological indicators of environmental change as diatoms are sensitive and respond to shifts in physico-chemical parameters in lotic and lentic ecosystems (Bere et al., 2013). As such, diatom community analysis can represent a tool with which to explore and interpret many ecological and environmental changes (Reynolds, 1984; Ács and Kiss, 1993).

An important aspect of community ecology is the identification of patterns in community structure relative to environmental gradients (Soininen et al., 2004). Characteristics of

To whom all correspondence should be addressed.

+27 46 622-8959; e-mail: dalutatenda@yahoo.co.uk Received 11 August 2013; accepted in revised form 18 June 2014. rivers, including unidirectional flow and continuous physical changes, make riverine ecology a unique avenue of study (Giller and Malmqvist, 1998; Soininen et al., 2004). For example, variation in river discharge as a result of freshwater input has a significant influence on primary production by benthic diatoms as shifts in flow affect diatom community composition (Stevenson, 1990). An increase in water flow (current) can positively affect the benthic algal community by increasing turbulent flux and thus the transport of nutrients to individual algal cells, thereby stimulating their metabolism (Miller et al., 1987; Ács and Kiss, 1993; Wehr and Sheath, 2003; Song 2007). Conversely, increased current velocity can also negatively affect benthic algal communities by decreasing immigration rates to the substrata and increasing the drag forces on attached algae which reduces the rate of colonisation of benthic diatoms and increases the sloughing of algal cells (Song, 2007). Flood effects on benthic diatoms increase with flood intensity, with effects ranging from scouring nearly all algae from substrates to having little effect on standing crops (Stevenson, 1990; Steinman and Mclntire, 1990).

River systems, from headwaters to estuaries, represent a continuum of interdependent habitats, so understanding diatom community structure at any place in a river requires an understanding of upstream properties (Gamier et al., 1995). As such, we have incorporated into our study design a spatial aspect which allows upstream and downstream comparisons of diatom community structure. Colonisation and development of diatoms has traditionally been studied by collecting benthic diatoms from a substratum over time (Lane, 2003). Artificial substrata have been used in diatom studies for many years. The advantages of using artificial substrates include decreased 


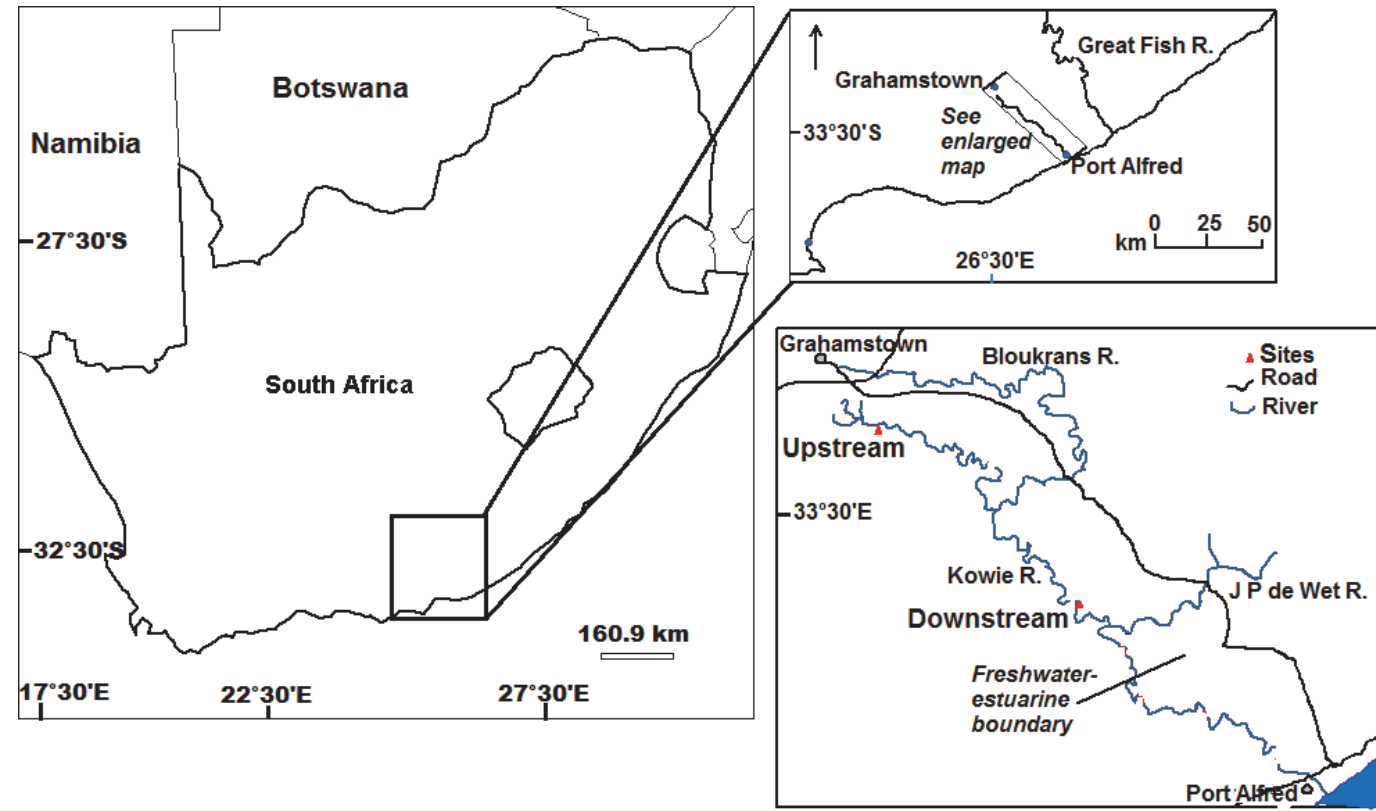

Figure 1

Position of artificial substrate stations in the Kowie River (Nov-Dec 2012)

habitat disruption and substantially improved sampling precision (Lane, 2003; Wojtal and Sobczyk, 2012). The use of artificial substrata also reduces the effects of small-scale habitat variations that inevitably exist in relation to natural substrata and ensures that diatom samples obtained are relatively stable (Lane et al., 2003; Wojtal and Sobczyk, 2012).

Diatoms have been studied extensively for many decades in South African river systems (Giffen, 1963; 1970; 1971; 1973; Schoeman and Archibald, 1976; Schoeman, 1982), and efforts have been made to relate diatom associations to water quality (Bate et al., 2002; 2004; Taylor et al., 2005a, b, c; Harding et al., 2005; Taylor et al., 2007). Few studies have been done on diatom colonisation and development patterns in South Africa. Therefore, our aim was to identify the environmental factors that affect benthic diatom community structure and development at 2 locations within a temperate South African river. We approached our aims by documenting the diatom communities on artificial substrata for 28 days following a major flooding event that occurred during October-November 2012, in order to study how the communities develop after a disturbance such as a flood.

\section{MATERIALS AND METHODS}

\section{STUDY AREA}

The Kowie River is found in the Eastern Cape Province of South Africa and drains a relatively small catchment area of approximately $800 \mathrm{~km}^{2}$ (Whitfield et al., 1994). The hills of Grahamstown Heights are the source of the river, from where it flows in a south-east direction, draining the major part of the Bathurst region (Fig. 1). Its major tributaries are the Bloukrans, Brakrivier and Lushington (or Torrens) Rivers. The total length of the Kowie River is approximately $70 \mathrm{~km}$. The river has a meandering course which has cut deeply into Bokkeveld shales which make up most of its catchment. Pineapple, citrus, chicory, fodder crops, beef cattle and goat farms occupy regions adjacent to upstream sections of the river. The river and its catchment fall within a temperate climate zone with rainfall occurring mainly during spring and autumn. Mean annual rainfall is $\approx 650 \mathrm{~mm}$, which is distributed evenly over the entire catchment (Heydorn and Grindley, 1982). Rain events in the catchment do not always result in increased river flow due to the presence of several impoundments along the length of the river system (Heydorn and Grindley, 1982; Bok, 1983; Whitfield et al., 1994).

The mean monthly rainfall values for the Kowie River in September, October and November 2012 were $38.2 \mathrm{~mm}, 432.1$ $\mathrm{mm}$ and $80.5 \mathrm{~mm}$, while discharge rates (and volumes) were estimated at $0.2 \mathrm{~m}^{3} \mathrm{~s}^{-1}\left(7.5 \times 10^{5} \mathrm{~m}^{3}\right), 1.1 \mathrm{~m}^{3} \cdot \mathrm{s}^{-1}\left(2.4 \times 10^{8} \mathrm{~m}^{3}\right)$ and $0.5 \mathrm{~m}^{3} \cdot \mathrm{s}^{-1}\left(5.8 \times 10^{6} \mathrm{~m}^{3}\right)$ (DWA, 2013). The mean yearly rainfall amounts (and discharge rates) for 2009-2012 were $537.0 \mathrm{~mm}$ $\left(0.07 \mathrm{~m}^{3} \cdot \mathrm{s}^{-1}\right), 638.0 \mathrm{~mm}\left(0.09 \mathrm{~m}^{3} \cdot \mathrm{s}^{-1}\right), 1029.4 \mathrm{~mm}\left(3.6 \mathrm{~m}^{3} \cdot \mathrm{s}^{-1}\right)$ and $989.7 \mathrm{~mm}\left(8.4 \mathrm{~m}^{3} \cdot \mathrm{s}^{-1}\right)$ (DWA, 2013; Fig. 2).

Benthic diatom sampling was conducted every 7 days from 16 November to 13 December 2012. The two study sites, $25 \mathrm{~km}$ apart, were located upstream ( $\left.33^{\circ} 20^{\prime} 59.2^{\prime \prime S} 026^{\circ} 33^{\prime} 37.6^{\prime \prime} \mathrm{E}\right)$ and downstream $\left(33^{\circ} 30^{\prime} 16.0^{\prime \prime} \mathrm{S} 026^{\circ} 44^{\prime} 40.9^{\prime \prime} \mathrm{E}\right)$ within the freshwater section of the Kowie River. The sites were chosen based on the river continuum concept (Vannote et al., 1980), which assumes that upstream areas are narrow and shaded and so allochthonous inputs are dominant. As a river widens downstream, energy inputs change as the sunlight reaches the benthos and supports increased autochthonous algal production. The upstream site had a mean water depth of $0.35 \pm 0.1 \mathrm{~m}$, a channel width of $1.8 \pm 0.3 \mathrm{~m}$ and $75 \%$ terrestrial cover from the riparian zone, while the downstream site had a mean water depth of $0.7 \pm 0.2 \mathrm{~m}$, a channel width of $7.5 \pm 0.2 \mathrm{~m}$ and $20 \%$ terrestrial cover.

\section{Physico-chemical parameters}

Physico-chemical data (temperature, $\mathrm{pH}$, dissolved oxygen, conductivity, total suspended solids (TDS), oxygen reduction potential (ORP), sodium chloride, resistivity and water transparency) of the sites were measured using a portable probe (CyberScan Series 600, Eutech Instruments, Singapore). Flow velocity was measured using a Flo-mate portable flowmeter Model 2000 (Marsh McBirney, Maryland). Water samples were collected according to Brendnock et al. (2003) and Wu et al. 

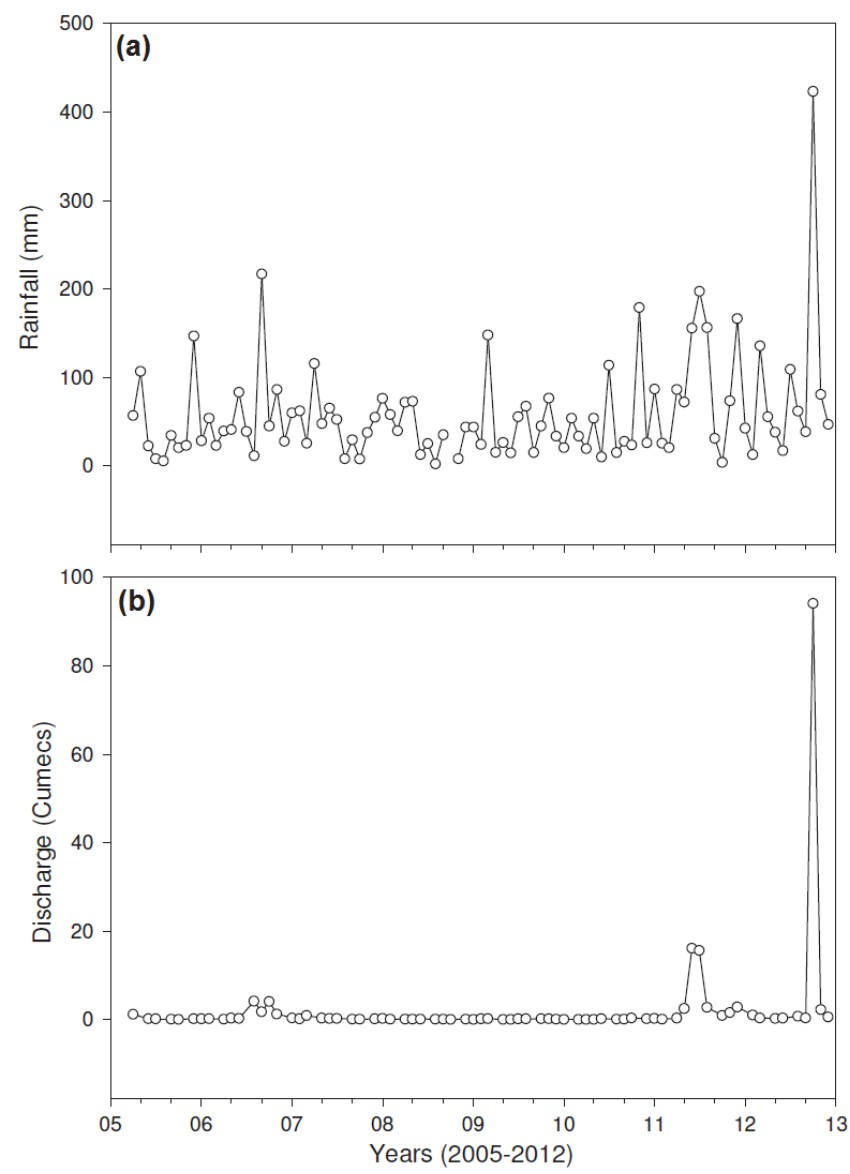

Figure 2

Mean (a) rainfall and (b) discharge trends measured by the Department of Water Affairs (South Africa) at Station P4HO01 (Kowie River, Bathurst). One cumec $=1 \mathrm{~m}^{3} \cdot \mathrm{s}^{-1}$.

(2011). At each site (Fig. 1), 3 water samples, one on either side of the river (littoral zones) and one at the centre, were collected using an $8 \ell$ bucket. All three water samples were pooled together in a $30-\ell$ bucket and stirred, after which a $500 \mathrm{~m} \ell$ sub-sample was taken as representative of the study site. The $500 \mathrm{~m} \ell$ sample was later processed to determine phosphate, nitrate and ammonia concentrations. Ammonia was analysed using a Nessler method, nitrate-cadmium reduction method and phosphate-amino acid method, using the HI 83203 multiparameter bench photometer for aquaculture (Hanna Instruments Inc., Rhode Island).

\section{Diatom sampling}

The artificial substrata used in this study were tiles (approximately $22 \times 10 \times 0.7 \mathrm{~cm}$ thickness). At each study site, 18 tiles were placed vertically in 6 tile structures $(30 \times 18 \mathrm{~cm})$ punctured with regular holes to allow the free flow of water around the tiles (Fig. 3), as per Peterson (1983), Lane et al. (2003) and Bere and Tundisi (2011). Each structure was anchored in the stream using a rope tied to the nearest tree in the riparian zone. When orientated vertically, the smooth surface of the tiles provided a substratum closely resembling the naturally occurring epilithon (Lane et al., 2003), while the rough side represented the rough material (rocks) washed into the river channel. Thus, it was our assumption that the tiles represented the different cleared habitats available for diatom colonisation following flooding events.

At each sampling event, 4 tiles were randomly selected from the 3 tile structures which were haphazardly placed within the river channel at each site. The tiles were carefully removed from the tile structures in the stream and the diatoms were then removed by brushing them with a toothbrush into a container with distilled water to form one integrated sample for that particular site. This procedure reduced the effects of heterogeneity between tiles that may result from contamination, microhabitat conditions that vary with position in the tray, or natural variation (Lane et al., 2003; Taylor et al., 2005c). The diatom material was then preserved in $70 \%$ ethanol until analysis.

\section{Diatom preparation and analysis}

Diatoms were prepared by oxidising organic material in samples with hydrochloric acid and potassium permanganate (Taylor et al., 2005). Clean diatom frustules were mounted in a synthetic resin with high refraction index (1.73) and counted and identified to the lowest taxonomic level possible (usually species) using a phase-contrast Olympus CX light microscope with 1000 x magnification. Keys by Giffen (1970) and Taylor et al. (2007) were used for diatom identification. Data were presented as species percentage abundances relative to the total abundance for each sampling occasion.

\section{Data analysis}

\section{Diversity index}

The Shannon-Weiner $(H)$ diversity index (Shannon and Weiner, 1949) was used to assess the diatom community
Figure 3

Artificial tile structures used for benthic diatom experiments in the Kowie River

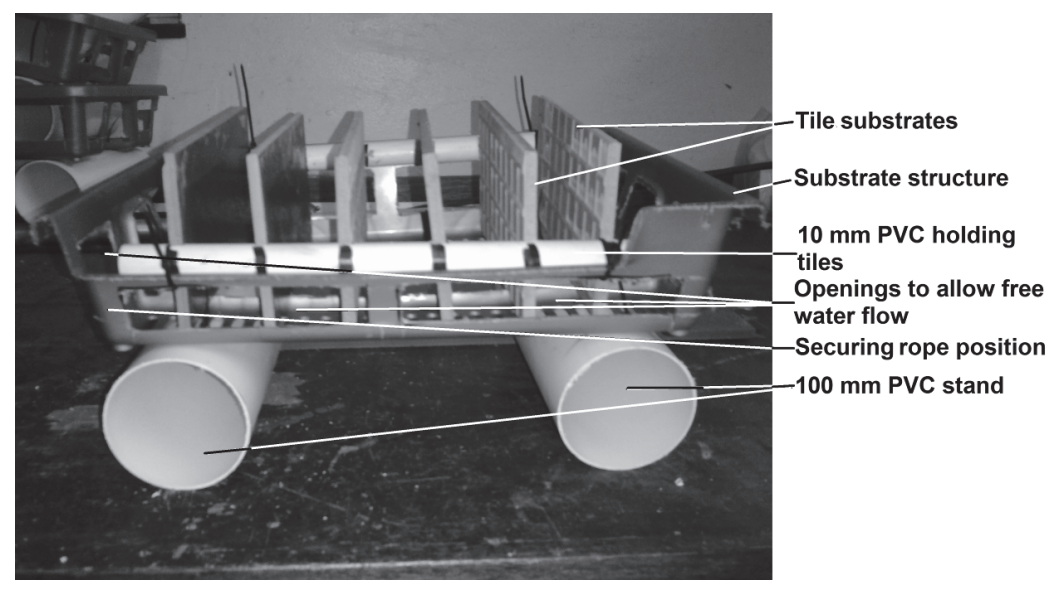


TABLE 1

Physico-chemical variables at the study sites sampled in November and December 2012. D -downstream site; U upstream site, ORP - oxygen reduction potential

\begin{tabular}{|c|c|c|c|c|c|c|c|c|c|c|}
\hline \multirow[t]{2}{*}{ Parameter } & \multicolumn{2}{|c|}{ 16-Nov } & \multicolumn{2}{|c|}{ 23-Nov } & \multicolumn{2}{|c|}{ 29-Nov } & \multicolumn{2}{|c|}{ 06-Dec } & \multicolumn{2}{|c|}{ 13-Dec } \\
\hline & $\mathrm{D}$ & $\mathrm{U}$ & $\mathrm{D}$ & $\mathrm{U}$ & $\mathrm{D}$ & $\mathrm{U}$ & $\mathrm{D}$ & $\mathrm{U}$ & D & $\mathrm{U}$ \\
\hline Dissolved oxygen $\left(\mathrm{mg} \cdot \ell^{-1}\right)$ & 5.33 & 5.89 & 6.39 & 6.54 & 6.20 & 5.99 & 7.02 & 6.25 & 5.61 & 6.03 \\
\hline Conductivity $\left(\mathrm{mS} \cdot \mathrm{cm}^{-1}\right)$ & 2.53 & 0.41 & 2.94 & 0.36 & 3.18 & 0.42 & 3.45 & 0.39 & 3.75 & 0.26 \\
\hline Total dissolved solids $\left(\mathrm{mg} \cdot \ell^{-1}\right)$ & 1.70 & 0.27 & 1.97 & 0.24 & 2.13 & 1.16 & 2.31 & 0.25 & 2.52 & 0.26 \\
\hline Salinity $\left(\mu \mathrm{S} \cdot \mathrm{cm}^{-1}\right)$ & 1.24 & 0.2 & 1.45 & 0.18 & 1.56 & 1.63 & 1.69 & 0.18 & 1.87 & 0.19 \\
\hline Resistivity $(\Omega)$ & 215.20 & 1339 & 186.30 & 1482 & 224.30 & 170.90 & 157.60 & 1450 & 145.50 & 1409 \\
\hline $\mathrm{pH}$ & 8.60 & 6.50 & 8.30 & 6.40 & 8.90 & 7.50 & 7.20 & 5.60 & 7.60 & 5.50 \\
\hline Temperature $\left({ }^{\circ} \mathrm{C}\right)$ & 23.50 & 20.80 & 22.90 & 19.90 & 22.40 & 23.20 & 21.20 & 20.90 & 22.70 & 18.10 \\
\hline $\mathrm{ORP}(\mathrm{mV})$ & -93.30 & -8.90 & -78.90 & 34.00 & -108.70 & -33.00 & -10.90 & 81.20 & -36.10 & 88.00 \\
\hline Water flow $\left(\mathrm{ms}^{-1}\right)$ & 1.71 & 0.86 & 0.84 & 0.29 & 0.58 & 0.74 & 0.68 & 0.47 & 0.55 & 0.28 \\
\hline \multicolumn{11}{|l|}{ Ammonia $\left(\mathrm{mg}^{-1}\right)$} \\
\hline $\mathrm{NH}_{3}-\mathrm{N}$ & 0.05 & 0.16 & 0.00 & 0.19 & 0.30 & 0.09 & 1.23 & 0.75 & 0.00 & 0.11 \\
\hline $\mathrm{NH}_{3}$ & 0.06 & 0.20 & 0.00 & 0.23 & 0.36 & 0.11 & 1.47 & 0.91 & 0.00 & 0.13 \\
\hline $\mathrm{NH}_{4}^{+}$ & 0.06 & 0.21 & 0.00 & 0.25 & 0.39 & 0.12 & 1.51 & 0.97 & 0.00 & 0.14 \\
\hline \multicolumn{11}{|l|}{ Phosphates $\left(\mathrm{mg} \cdot \ell^{-1}\right)$} \\
\hline $\mathrm{PO}_{3}^{-4}$ & 1.20 & 0.70 & 1.60 & 0.20 & 28.40 & 1.50 & 6.30 & 4.10 & 1.30 & 2.50 \\
\hline $\mathrm{P}$ & 0.40 & 0.20 & 0.50 & 0.10 & 9.30 & 0.50 & 2.90 & 1.30 & 0.40 & 0.80 \\
\hline $\mathrm{P}_{2} \mathrm{O}_{5}$ & 0.90 & 0.50 & 1.20 & 0.20 & 21.20 & 1.10 & 4.80 & 3.00 & 0.90 & 1.80 \\
\hline \multicolumn{11}{|l|}{ Nitrates $\left(\mathrm{mg} \cdot \ell^{-1}\right)$} \\
\hline $\mathrm{NO}_{3}^{-}-\mathrm{N}$ & 0.50 & 0.00 & 1.80 & 0.00 & 0.00 & 3.40 & 0.10 & 4.00 & 2.00 & 3.40 \\
\hline $\mathrm{NO}_{3}^{-}$ & 2.30 & 0.00 & 8.00 & 0.00 & 0.00 & 15.10 & 0.00 & 17.60 & 8.80 & 14.90 \\
\hline
\end{tabular}

diversity at the two study sites throughout the study period;

$$
H=\sum_{i}^{n} p_{i} \ln p_{i}
$$

where:

$H$ is the Shannon-Wiener index

$p_{i}$ is the proportional abundance of species $i$ through $n$

\section{Redundancy analysis}

Redundancy analysis (RDA) is a constrained linear ordination method based on significant $(p<0.05)$ forward selected environmental variables using 999 Monte Carlo permutations (Ter Braak, 2002). Only those diatom species that contributed $>1 \%$ to the relative abundance ( 28 taxa in total) were included in the RDA, to eliminate the effects of rare species. All chemical and diatom raw abundance data were log-transformed before RDA analysis. RDA was performed to examine the relationships between diatom species composition and the selected environmental variables measured during the study. Detrended canonical correspondence analysis (DCCA) was employed to determine whether linear or unimodal analysis methods should be used (Leps and Šmilauer, 2003). The gradient lengths from the DCCA output were examined, and, since the longest gradient was between 3 and 4, a linear RDA model was selected (Leps and Šmilauer, 2003). All ordinations were performed using CANOCO version 4.5 (Ter Braak and Šmilauer, 2002).

\section{RESULTS}

\section{Flood event}

Heavy rainfall produced a strong flooding of freshwater $(2.7 \mathrm{x}$ $10^{8} \mathrm{~m}^{3}$ ) along the Kowie River for 12 days. The total rainfall for this period (17-28 October) was $418 \mathrm{~mm}$. The discharge rate increased from $0.70 \mathrm{~m}^{3} \cdot \mathrm{s}^{-1}$ on 16 October to a peak of $699.14 \mathrm{~m}^{3} \cdot \mathrm{s}^{-1}$ on 21 October, while the river volume increased from $6.0 \times 10^{4}$ $\mathrm{m}^{3}$ on Oct 16 to a peak of $6.0 \times 10^{7} \mathrm{~m}^{3}$ on 21 October). Discharge rates and volume remained elevated until 21 November, with values of $1.06 \mathrm{~m}^{3} \cdot \mathrm{s}^{-1}$ and $9.16 \times 10^{4} \mathrm{~m}^{3}$, respectively.

\section{Physico-chemical parameters}

Dissolved oxygen concentrations at the two sites ranged between

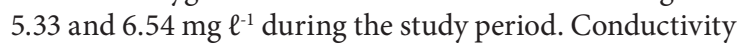
downstream increased from 2.53 to $3.75 \mathrm{mS} \cdot \mathrm{cm}^{-1}$, while it was relatively constant upstream (range $0.26-0.41 \mathrm{mS} \cdot \mathrm{cm}^{-1}$ ) over the study period. The $\mathrm{pH}$ values ranged between 7.21 and 8.62 at the downstream site, and 5.5 and 7.51 at the upstream site (Table 1). Mean concentrations of phosphates ranged from 0.8 to $19.6 \mathrm{mg} \cdot \ell^{-1}$ downstream and 0.2 to $2.8 \mathrm{mg} \cdot \ell^{-1}$ upstream, while

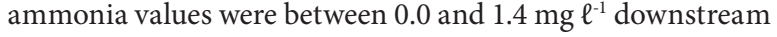
and 0.1 and $1 \mathrm{mg} \cdot \ell^{-1}$ upstream. Nitrates were generally high (0-8.8 $\mathrm{mg} \cdot \ell^{-1}-$ downstream and $14.9-17.6 \mathrm{mg} \cdot \ell^{-1}-$ upstream) during the last 14 days of the study at the two sites (Table 1). Some environmental variables were not spatially distinct (Mann Whitney $\mathrm{U}$ tests, $p>0.05$ ), but TDS, salinity, resistivity, $\mathrm{pH}$ and ORP did show significant differences between the sites $(p<0.05)$.

\section{Diatom communities and succession}

Fifty-eight (58) diatom species belonging to 30 genera were identified over the period of study (Table 2). The species richness at both sites increased from minima on 13 November (downstream - 17 and upstream - 13) to maxima on 6 December (22 species at both sites). Achnanthidium, Pinnularia, Achnanthes, Brachysira and Fragilaria genera were the most numerically dominant on 23 November downstream, while upstream the diatom 
TABLE 2

Percentage species abundance of diatoms growing on tile substrates at the study sites

\begin{tabular}{|c|c|c|c|c|c|c|c|c|}
\hline \multirow[t]{2}{*}{ Species name } & \multicolumn{4}{|c|}{ Downstream } & \multicolumn{4}{|c|}{ Upstream } \\
\hline & $\begin{array}{l}23- \\
\text { Nov } \\
\end{array}$ & $\begin{array}{l}29- \\
\text { Nov }\end{array}$ & $\begin{array}{l}\text { 06- } \\
\text { Dec }\end{array}$ & $\begin{array}{l}13- \\
\text { Dec }\end{array}$ & $\begin{array}{l}23- \\
\text { Nov } \\
\end{array}$ & $\begin{array}{l}29- \\
\text { Nov }\end{array}$ & $\begin{array}{l}\text { 06- } \\
\text { Dec }\end{array}$ & $\begin{array}{l}13- \\
\text { Dec }\end{array}$ \\
\hline Achnanthes oblongella Østrup & 0.8 & & & & & & & \\
\hline Achnanthes standeri Cholnoky & 5.0 & 2.9 & 1.7 & 4.1 & & & & \\
\hline Achnanthes subaffinis Cholnoky & 1.7 & 1.4 & & & & & & \\
\hline Achnanthidium minutissimum (Kützing) Czarnecki & 15.8 & 5.7 & & & & & & 11.2 \\
\hline Achnanthes coarctata (Brébisson ex W. Smith) Grunow & & & & & 4.0 & & & \\
\hline Amphora pediculus (Kützing) Grunow & & 3.8 & & & & & & \\
\hline Asterionella formosa Hassal & & & & & & 2.3 & & \\
\hline Brachysira neoexilis (Grunow) DG Mann & 5.4 & & & & & 16.1 & 4.3 & 2.7 \\
\hline Caloneis schumanniana (Grunow) Cleve & & & & & & & 0.4 & \\
\hline Cocconeis placentula Ehrenberg & & & & & 8.0 & & & \\
\hline Craticula buderi (Hustedt) & & & & & 1.1 & 2.1 & 2.9 & 10.9 \\
\hline Craticula cuspidata (Kützing) DG Mann & & & 0.8 & 3.2 & & & & \\
\hline Craticula vixnegligenda Lange-Bertalot & 7.5 & 14.3 & 3.9 & 14.7 & & 16.0 & 14.0 & 9.4 \\
\hline Cyclotella meneghiniana Kützing & & 1.4 & 1.5 & 0.9 & & & & \\
\hline Cymbella kappii (Cholnoky) Cholnoky & & & 2.0 & & & & & \\
\hline Diatoma vulgaris Bory & & 0.5 & 3.4 & 0.9 & & & & \\
\hline Diploneis subovalis Cleve & & 10.0 & 23.7 & 18.8 & & & & \\
\hline Encyonema caespitosum Kützing & & & & 1.8 & & & & \\
\hline Encyonopsis microcephala (Grunow) Krammer & & & & & & & & 2.1 \\
\hline Epithemia adnata (Kützing) Brébisson & & & & 0.6 & & & & \\
\hline Eunotia formica Ehrenberg & & & & 5.9 & & & 1.7 & 5.5 \\
\hline Eunotia incisa Gregory & & & & & 1.1 & & & \\
\hline Eunotia lunaris (Ehrenberg) Grunow & & & & & & 2.2 & & \\
\hline Eunotia minor (Kützing) Grunow & & & & & & & & 0.9 \\
\hline Fragilaria biceps (Kützing) Lange-Bertalot & & 1.4 & & & 41.4 & 15.5 & 16.6 & 1.8 \\
\hline Fragilaria capucina Desmazières & & & & & & 6.1 & 5.4 & 14.5 \\
\hline Fragilaria capucina var. rumpens (Kützing) Lange-Bertalot & 8.8 & 3.3 & 7.9 & 6.2 & & & & 5.8 \\
\hline Fragilaria capucina var. vaucheriae (Kützing) Lange-Bertalot & 3.8 & & & & & 4.6 & 6.6 & 9.1 \\
\hline Fragilaria tenera (WM Smith) Lange-Bertalot & 5.8 & 3.3 & 0.6 & & & & & 3.9 \\
\hline Fragilaria ulna var. acus (Kützing) Lange-Bertalot & 1.3 & & & & 16.7 & 5.5 & 19.5 & 1.5 \\
\hline Gomphonema acuminatum Ehrenberg & 2.1 & & 0.8 & 2.4 & & 1.9 & 1.8 & 1.2 \\
\hline Gomphonema angustatum (Kützing) Rabenhorst & & & & & 3.4 & 6.1 & 3.3 & \\
\hline Gomphonema laticollum Reichart & & & & 5.3 & & & & \\
\hline Gomphonema parvulius Lange-Bertalot \& Reichardt & & & & & & & 2.9 & \\
\hline Gomphonema pseudoaugur Krammer & & 7.6 & 3.4 & & & & & \\
\hline Gomphonema truncatum Ehrenberg & & 6.7 & 4.9 & 4.4 & & & & \\
\hline Gomphonema venusta Passy, Kociolek \& Lowe & 3.8 & 7.6 & 3.9 & 10.0 & & & & \\
\hline Gyrosigma acuminatum (Kützing) Robenhorst & & & & 0.3 & & & & \\
\hline Hantzschia amphioxys (Ehrenberg) Grunow & 2.5 & & & & & & 0.4 & 9.7 \\
\hline Melosira varians Agardh & & & 2.3 & 0.6 & & & 1.7 & \\
\hline Navicula cryptolenelloides & & & & & & 1.7 & 4.0 & \\
\hline Navicula cryptotenella Lange-Bertalot & & & & & & 2.2 & 2.1 & \\
\hline Navicula radiosa Kützing & & & & & & & & 2.7 \\
\hline Navicula rhynchocephala Kützing & 4.6 & 1.9 & 5.6 & & 0.6 & 1.2 & 1.5 & 2.1 \\
\hline Nitzschia bacillum Hustedt & & & & 0.6 & & & & \\
\hline Pinnularia acrosphaeria W Smith & 14.2 & 10.5 & & & & & & \\
\hline Pinnularia borealis Ehrenberg sensu lato & 15.8 & 11.4 & 7.9 & 9.7 & & & & \\
\hline Pinnularia divergens var. undulata (Peragallo \& Heribaud) & & & & & & 6.6 & 2.8 & 2.4 \\
\hline Pinnularia gibba (Ehrenberg) Grunow & & & & & 1.1 & & & \\
\hline Pinnularia viridiformis Krammer & & & 4.0 & & 5.2 & 3.9 & & \\
\hline
\end{tabular}




\begin{tabular}{|c|c|c|c|c|c|c|c|c|}
\hline \multicolumn{9}{|c|}{$\begin{array}{l}\text { TABLE } 2 \text { (continued) } \\
\text { Percentage species abundance of diatoms growing on tile substrates at the study sites }\end{array}$} \\
\hline $\begin{array}{l}\text { Planothidium frequentissimum (Lange-Bertalot) Round \& } \\
\text { Bukhityarova }\end{array}$ & & 5.2 & & & & & & \\
\hline $\begin{array}{l}\text { Pseudostaurosira brexistriata (Grunow in Van Heurk) Williams } \\
\text { \& Round }\end{array}$ & & & 0.6 & & & & & \\
\hline Reimeria uniseriata Sala, Guerrero \& Ferrario & & & & & 2.8 & & & \\
\hline Staurosira elliptica (Schumann) Williams \& Round & & & 9.3 & 7.9 & 6.4 & 2.8 & 1.9 & 1.2 \\
\hline Stenopterobia delicatissima (Lewis) Brebisson & & & & & & & 0.8 & \\
\hline Surirella brebissonii Krammer \& Lange-Bertalot & 1.3 & & 10.4 & 1.2 & & & 1.7 & 1.2 \\
\hline Tabularia fasciculata (Agardh) Williams \& Round & & 1.0 & 0.8 & 0.6 & 8.1 & 3.3 & 3.7 & \\
\hline Tryblionella apiculata Gregory & & & 0.6 & & & & & \\
\hline Species richness & 17 & 19 & 22 & 21 & 13 & 18 & 22 & 20 \\
\hline Shannon-Wiener & 2.52 & 2.66 & 2.63 & 2.57 & 1.92 & 2.57 & 2.62 & 2.67 \\
\hline Evenness & 0.73 & 0.75 & 0.63 & 0.62 & 0.53 & 0.73 & 0.62 & 0.72 \\
\hline
\end{tabular}

community was numerically dominated by Fragilaria, Cocconeis, Staurosira and Tabularia. These genera could be considered as the early colonisers. On 13 December Craticula, Diploneis, Gomphonema and Eunotia genera dominated downstream, while at the upstream site on 13 December Achnathidium, Craticula, Hantzschia and Eunotia were dominant; these genera represent the intermediate to late colonisers (Table 2). No major differences in Shannon-Wiener $(H)$ diversity index occurred downstream throughout the study period, as the values ranged from 2.52 2.66, while upstream the $H$ index values gradually increased from 23 November (1.92) to Dec 13 (2.67).

The first two axes of the RDA, with eigenvalues of 0.45 in Axis 1 and 0.17 in Axis 2, accounted for $73.4 \%$ of the speciesenvironment relationship while also accounting for $62.1 \%$ of the variance in the species data (Fig. 4). Diatom species composition differed over time in both locations (Fig. 4). Upstream there was a large difference in diatom communities between 23 November and the other three sampling times. In contrast, there were fewer changes in the diatom community through time at the downstream location. There were clear distinctions in the environmental factors associated with diatom community structure at the two locations (Table 1). The RDA analysis identified 7 physico-chemical factors that were significant $(p<0.05)$ in affecting diatom community variation, these being nitrates, phosphates (P), TDS, salinity, $\mathrm{pH}$, resistivity and water flow (Fig. 4).

\section{DISCUSSION}

\section{Physico-chemical factors}

Discharge rate and volume continued to be high up until 21 November, while rainfall decreased. Along the Kowie River, the upstream location had significantly decreased conductivity, TDS, pH, water flow, salinity, temperature, phosphates and DO due to the pristine nature of the site and minimal human influences compared to the downstream location, which was influenced by agricultural activities (crop and cattle farming) and wastewater discharge. In contrast, ammonia and nitrates were high upstream relative to downstream. This suggests the influence of natural, mature forests which conserve nitrogen and release it through processes of decomposition and leaching (Hallberg and Keeney, 1993).

Downstream of the headwaters, the Kowie River's riparian

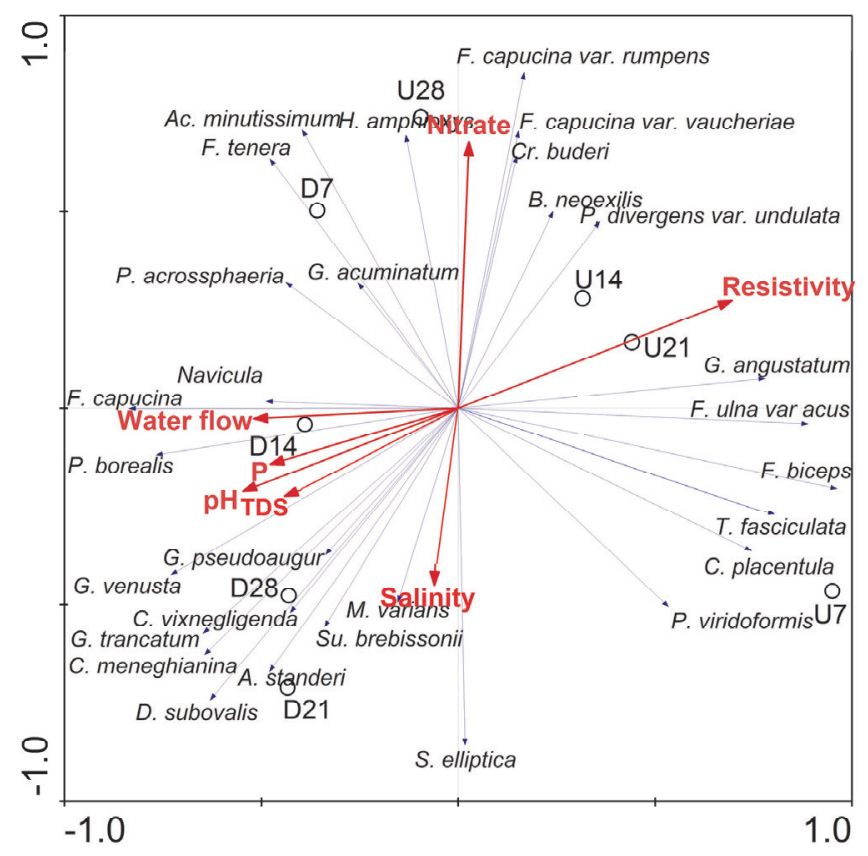

Figure 4

RDA ordination showing the relationship between diatom community composition and the significant environmental variable. Letters in sample labels represent sites ( $U$, upstream; $D$, downstream). Numbers in labels represent sampling dates (23 Nov, 29 Nov, 6 Dec and $13 \mathrm{Dec}$ ).

zone cover begins to decrease as the river passes through several game reserves, cultivated farms and ranches. One of the main tributaries of the Kowie River, the Bloukrans River, joins the main channel and contributes to the high phosphate loads observed downstream (Whitfield et al., 1994). Riparian buffer strips or zones are observed along the whole river channel, but these are interspersed with game reserves, pineapple plantations and cattle ranching.

\section{Diatom community structure in relation to environmental variables}

The benthic diatom community structure on tiles at both sites was structured by environmental variables, with grouping 
of sites generally reflecting a change in diatom community composition between sampling periods. Different diatom species and communities responded to changes in TDS, salinity, resistivity, $\mathrm{pH}, \mathrm{P}$ and water flow because of their differences in tolerances and adaptations; hence the distinct diatom community composition at different sampling sites.

The upstream location had almost similar diatom communities for Days 14 and 21, but the communities were very different on Day 7 and Day 28. At the downstream site, the diatom communities were significantly different from week to week, which can be a result of natural succession. Water flow likely excluded some algal taxa in our study of Kowie diatom communities, especially the large-celled long filamentous algae such as Fragilaria spp. that tend to prefer slow currents with fine sediments as their substrata (Claquin et al., 2006). Current flow indirectly modulates benthic algal community structure by interacting with both the biotic and abiotic factors in different habitats, such as substratum type, size and stability, or by altering the diatom species composition, community and distribution via the control of invertebrate grazers and fish through feeding or physical disturbances (Song, 2007).

Benthic diatom communities are considered to be regulated by local physico-chemical factors rather than by broad-scale climatic factors (Pan et al., 1996), but Mann and Droop (1996) argued that a considerable number of diatoms are endemic and/or show a regionally restricted distribution. Our study results support the view of Mann and Droop (1996) that diatom communities are strongly affected by physico-chemical factors, with different diatom communities being recorded at different locations or study sites within the Kowie River. Most taxa in this study were truly cosmopolitan but a number of the species exhibited limited distributions, with TDS, salinity, resistivity, $\mathrm{pH}, \mathrm{P}$ and water flow playing an important role in the diatom distribution patterns.

Water flow was one important variable structuring diatom communities in the study (Fig. 4). Low water flow (upstream) was associated with the diatom species generally considered as 'cool adapted' (Ruth, 1977; Bere et al., 2013), including Craticula buderi, Gomphonema angustatum, Navicula cryptotenelloides, N. cryptotenella and Pinnularia divergens var. undulata. The downstream site, which had high water flow, was associated with Achnanthes subaffinis, A. standeri, Achnanthidium minutissimum, Cyclotella meneghiniana, Diatoma vulgaris, Diploneis subovalis, Gomphonema pseudoagur, G. truncatum, G. venusta, Pinnularia borealis and $P$. acrosphaeria which were considered 'locals'. These species may have developed morphological adaptations to different water flow regimes which enabled them to be better suited to their environment. Ruth (1977) and Claquin et al. (2006) highlighted that smaller diatoms predominate under conditions of high water flow in lotic systems, which was the case in our study - the downstream site was dominated by small-sized diatoms. Song (2007) showed that there was a shift from dominance by large-celled upright filamentous taxa at low water flow to smaller chain-forming taxa at higher water flow, in response to changes in water flow in the Maple River, Michigan.

The $\mathrm{pH}$ levels also played an important role in structuring benthic diatom communities in this study. The $\mathrm{pH}$ levels affect diatom motility and adhesion to surfaces. The affinities of diatoms to various cations have not been sufficiently investigated or demonstrated, but are likely to be linked to physiological mechanisms (Bere et al., 2013). The $\mathrm{pH}$ level can exert a direct physiological stress on diatoms and also strongly influences other water chemistry variables such as resistivity and conductivity (Bere and Tundisi, 2011). The $\mathrm{pH}$ values at the upstream site were largely alkaline (6.4-8.9), while at the downstream site they were circumneutral; thus most of the species were either alkaliphilic or circumneutral-tolerant. A decrease in $\mathrm{pH}$ downstream may have had an influence on diatom population growth and development in A. standeri, F. capucina, G. trancatum, G. venusta and P. borealis, which are weakly alkaline to slightly acidic environment species, while an increase in $\mathrm{pH}$ had an influence on upstream species, F. ulna var. acus, F. biceps and G. angustatum, which are alkaliphilic species (Taylor et al., 2007; Koçer and Şen, 2012). TDS, which is commonly used as an indicator of the presence of a broad array of chemical contaminants (Jorgensen, 1996), was also important in structuring diatom communities. The distribution of moderate- to high-electrolyte content species such as A. standeri, D. subovalis, F. capucina, G. trancatum, G. venusta, $P$. pseudoagur and P. borealis (Taylor et al., 2007) were influenced by TDS concentrations in this study, as clearly reflected in the RDA graph.

Resistivity levels were also important in structuring diatom community structure with the downstream warmer site associated with low resistivity levels. Resistivity of water is a measure of the ability of the water to resist an electric current, and is directly related to the amount of ionic material, mainly salts, in the water (Jorgensen, 1996). Thus, water with a relatively high TDS will have a low resistivity and a high conductivity (Jorgensen, 1996). Species such as F. ulna var. acus, F. biceps, G. angustatum and T. fasciculata, which are mostly cosmopolitan, inhabit different electrolyte content habitats, have low conductivity and alkalinity tolerances, and hence are greatly influenced by resistivity, which is an indirect measure of these two parameters (Taylor, 2007).

Nitrate concentration was identified as one of the main factors structuring diatom communities within the upstream site. The upstream site was associated with high nitrate concentrations, with Days 7,21 and 28 being separated from the rest of the time period. Nitrate concentration is an important nutrient required for diatom growth and has an important function in the structuring of benthic diatom communities in river systems (Bere et al., 2013). Diatoms in the upstream sites influenced by nitrate concentration included Hantzschia amphioxys, G. angustatum, Fragilaria capucina var. rumpens, F. capucina var. vaucheriae, Brachysira neoexilis and P. divergens var. undalata.

\section{Benthic diatom colonisation and development}

Benthic diatom colonisation and development on tile surfaces is the direct consequence of immigration, reproduction, disturbance, death, grazing and emigration (Ruth, 1977; Peterson, 1986; Delesalle, 1993; Claquin et al., 2006; Power et al., 2008; Bere and Tundisi, 2011; Koçer and Şen, 2012; Bere et al., 2013). Periods of 3 to 4 weeks have been sufficient for benthic diatom colonisation and development, which are dependent on algal abundance and biomass in the water column (Peterson, 1983; Lane et al., 2003; Bere and Tundisi, 2011; Kralj et al., 2006). The numerically dominant benthic diatom genera found in this study, especially Cocconeis, Cymbella, Fragilaria, Gomphonema, Pinnularia and Epithemia, are important components of stream diatom communities worldwide (Lane et al., 2003; Claquin et al., 2006; Koçer and Şen, 2012).

In our study, the species richness peaked after 21 days and seemed to stabilise thereafter at both sites. There was significant arrival of new colonisers within the first 14 days, e.g., the 
Achnanthes, Achnanthidium and Pinnularia genera (downstream) and Cocconeis and Gomphonema spp. upstream. All of the observed new coloniser genera at both sites have high immigration rates and respond better than other genera to disturbance, which enables them to populate surfaces before other competitors (Stevenson, 1990). Other pioneer colonists, such as Fragilaria spp. observed at both sites, were mostly relatively large and had an advantage during immigration in that they can settle rapidly to the substrate (Stevenson, 1990; Krajl et al., 2006). Fragilaria spp., which are non-motile and not very good competitors during later stages of colonisation, were shown to decrease in their abundances with time (Table 2). Craticula, Diploneis, Gomphonema, Staurosira and Eunotia spp. at the downstream site, and Brachysira, Craticula, Hantzschia, Navicula and Eunotia spp. at the upstream site, were dominant as time progressed. These are considered as intermediate to late colonisers, as most of these genera have low (slow) immigration ability but their small size makes them fast reproducers, and they are probably better competitors in nutrient-rich environments than the other species mentioned.

The Shannon-Wiener diversity index increased downstream up to Day 21 before decreasing, but continued to increase upstream. This may be explained by the fact that more new species were still migrating to tiles upstream (Table 2) after Day 21, suggesting that the population had not yet reached stability, whereas the downstream site after Day 21represented the late stages of diatom community development, during which competition might be a factor causing a decrease in diversity (Krajl et al., 2006).

\section{CONCLUSION}

Diatom colonisation and development in the Kowie River, Eastern Cape, was governed by physico-chemical factors such as water flow, resistivity, phosphates, $\mathrm{pH}$, salinity, TDS and nitrates. This result corroborates the classic subsidy-stress gradient model of Odum et al. (1979), which states that smallscale perturbations involving usable nutrients would stimulate ecosystem function, while continued perturbation would have a negative impact on community equilibrium and functioning. Since benthic diatom communities recycle nutrients, and use recycled nutrients within the community for some time, this isolates benthic diatom communities from the influence of external nutrient inputs, which can be advantageous to their survival because most of the inputs from the water column can then be used to increase net growth and production (Wetzel, 1993). The flood event in the Kowie River caused a major perturbation which heavily affected the benthic diatom community equilibrium and functioning by affecting nutrient sources and community structure, as most diatoms were washed away by the flood. Long-term monitoring studies are clearly required to better understand the colonisation, development, succession and productivity of diatoms in flowing waters (streams and rivers).

\section{ACKNOWLEDGEMENTS}

This work was supported by the Water Research Commission of South Africa (Project K5/2186), The National Research Foundation of South Africa and Rhodes University's Sandisa Imbewu initiative. The Eastern Cape Department of Economic Development, Environmental Affairs and Tourism provided the collection permit (CRO 116/12CR). We are grateful to Jonathan C Taylor, North-West University, for helping with the diatom identification manuals and methods and Likho Sikutshwa for assistance with the field work.

\section{REFERENCES}

ÁCS É and KISS KT (1993) Colonisation processes of diatoms on artificial substrates in the River Danube near Budapest (Hungary). Hydrobiologia 269/270 307-315.

BATE G, SMAILES P and ADAMS J (2004) A water quality index for use with diatoms in the assessment of rivers. Water SA 30 493-49.

BATE GC, ADAMS JB and VAN DER MOLEN JS (2002) Diatoms as indicators of water quality in South African river systems. WRC Report No. 814/1/02. Water Research Commission, Pretoria.

BERE T, PHIRI C, KADYE WT and UTETE B (2013) Benthic diatom assemblages in mountain streams: community structure in relation to environmental and human pressures. Afr. J. Ecol. DOI: 10.1111/ aje. 12078

BERE T and TUNDISI JG (2011) Diatom-based water quality assessment in streams influence by urban pollution: effects of natural and two selected artificial substrates, São Carlos-SP, Brazil. Braz. J. Aquat. Sci. Technol. 15 54-63.

BOK A (1983) The demography, breeding biology and management of two mullet species (Pisces: Mucilidae) in the eastern cape, South Africa. PhD thesis, Rhodes University, Grahamstown.

BRENDONCK L, MAES J, ROMMENS W, DEKEZA N, NHIWATIWA T, BARSON M, CALLEBAUT V, PHIRI C, MOREAU K, GRATWICKE B, STEVENS M, ALYN N, HOLSTERS E, OLLEVIER F and MARSHALL BE (2003) The impact of water hyacinth (Eichhornia crassipes) in a eutrophic subtropical impoundment (Lake Chivero, Zimbabwe). II. Species diversity. Arch. Hydrobiol. 158 389-405.

CLAQUIN P, LEYNAERT A, SFERATORRE A, GARNIER J and RAGUENEAU O (2006) Physiological ecology of diatoms along the river-sea continuum: Diatom ecophysiology along the aquatic continuum from river to ocean. In: Ittekkot V, Unger D, Humborg C, Tac An N (eds.) The Silicon Cycle: Human Perturbations and Impacts on Aquatic Systems. SCOPE 66. Island Press, Washington DC. $121-138$.

DELESALLE B, PICHON M, FRANKIGNOULLE $M$ and GATTUSO J-P (1993) Effects of a cyclone on coral reef phytoplankton biomass, primary production and composition (Moorea Island, French Polynesia). J. Plankton Res. 15 1413-1423.

DWA (DEPARTMENT OF WATER AFFAIRS) (2013) Kowie River, Bathurst station P4H001. URL: http://www.dwa.gov.za/hydrology/ HyDataSets.aspx?Station=P4H001 (Accessed 30 April 2013).

GAMIER J, BILLEN G and COSTE M (1995) Seasonal succession of diatoms and Chlorophyceae in the drainage network of the Seine River: Observations and modelling. Limnol. Oceanogr. 40 750-765.

GIFFEN MH (1963) Contributions to the Diatom Flora of South Africa. I. Diatoms of the estuaries of the Eastern Cape Province. Hydrobiologia 21 201-265.

GIFFEN MH (1970) Contributions to the diatom flora of South Africa IV. The marine littoral diatoms of the estuary of the Kowie River, Port Alfred, Cape Province. Nova Hedwigia 31 259-312.

GIFFEN MH (1971) Marine littoral diatoms from the Gordon's Bay, Region of False Bay Cape Province, South Africa. Bot. Mar. 14 1-16.

GIFFEN MH (1973) Diatoms of the marine littoral of Steenberg's Cove in St. Helena Bay, Cape Province, South Africa. Bot. Mar. 16 32-48.

GILLER S and MALMQVIST B (1998) The Biology of Streams and Rivers. Oxford University Press, Oxford.

HA K, KIM HW and JOO GJ (1998) The phytoplankton succession in the lower part of hypertrophic Nakdong River (Mulgum), South Korea. Hydrobiologia 369/370 217-227.

HALLBERG GR and KEENEY DR (1993) Nitrate. In: Alley WA (ed.) Regional Groundwater Quality. Van Nostrand Reinhold, New York. 297-322.

HARDING WR, ARCHIBALD CGM and TAYLOR JC (2005) The relevance of diatoms for water quality assessment in South Africa: A position paper. Water $S A 31$ 41-46.

HEYDORN AEF and GRINDLEY JR (1982) Estuaries of the Cape. Part II: Synopses of available information on individual systems. 
Report No.10 Kowie (CSE 10). CSIR Research Report 409. CSIR, Pretoria.

JORGENSEN DG (1996) The ratio method of estimating water resistivity and TDS from resistivity logs. Groundwater 34 519-522.

KOÇER MAT and ŞEN B (2012) The seasonal succession of diatoms in phytoplankton of a soda lake (Lake Hazar, Turkey). Turk. J. Bot. 36 738-746.

KRALJ K, PLENKOVIĆ-MORAJ A, GLIGORA M, PRIMC-HABDIJA B and ŠIPOŠ L (2006) Structure of periphytic community on artificial substrata: influence of depth, slide orientation and colonization time in karstic Lake Visovačko, Croatia. Hydrobiologia $\mathbf{5 6 0}$ 249-258.

LANE CM, TAFFS KH and CORFIELD JL (2003) A comparison of diatom community structure on natural and artificial substrata. Hydrobiologia 493 65-79.

LEPS J and ŠMILAUER P (2003) Multivariate Analysis of Ecological Data Using CANOCO. Cambridge University Press, New York.

MANN DG and DROOP JM (1996) Biodiversity, biogeography and conservation of diatoms. Hydrobiologia 336 19-32.

MCCUNE B and MEFFORD MJ (2006) PC-ORD: Multivariate Analysis of Ecological Data. Version 5.10. MjM Software, Gleneden Beach, Oregon, USA.

MILLER AN, LOWE RL and ROTENBERRY JT (1987) Succession of diatom communities on sand. J. Ecol. 75 693-709.

ODUM EP, FINN JT and FRANZ EH (1979) Perturbation theory and the subsidy-stress gradient. Bioscience 29 344-352.

PAN Y, STEVENSON RJ, HILL BH, HERLIHY AT and COLLINS GB (1996) Using diatoms as indicators of ecological conditions in lotic systems: a regional assessment. J. N. Am. Benthol. Soc. 15 481-495

PETERSON CG (1986) Effects of discharge reduction on diatom colonisation below a large hydroelectric dam. J. N. Am. Benthol. Soc. 5 278-289.

POWER ME, PARKER MS and DIETRICH WE (2008) Seasonal reassembly of a river food web: floods, droughts, and impacts of fish. Ecol. Monogr. 78 263-282.

REYNOLDS CS (1984) The Ecology of Freshwater Phytoplankton. Cambridge University Press, New York.

RUTH P (1977) Ecology of freshwater: diatoms and diatom communities. In: Werner D (ed.) The Biology of Diatoms. Blackwell Scientific, London.

SCHOEMAN FR and ARCHIBALD REM (1976) The Diatom Flora of Southern Africa. Special report. National Institute for Water Research. Council for Scientific and Industrial Research. WT50. CSIR, Pretoria.

SCHOEMAN FR (1982) The diatoms of the Jukskei-Crocodile River system (Transvaal, Republic of South Africa): A preliminary checklist. S. Afr. J. Bot. 48 295-310.

SHANNON CE and WIENER W (1949) The Mathematical Theory of Communications. University of IIinois Press, Urbana.
SOININEN J, PAAVOLA R and MUOTKA T (2004) Benthic diatom communities in boreal streams: community structure in relation to environmental and spatial gradients. Ecography 27 330-342.

SONG X (2007) Trends in benthic algal community response to a small-scale gradient of current velocities along a streambed transect. MSc thesis, Graduate College of Bowling Green State University, United States of America.

STEINMAN AD and McLNTIRE CD (1990) Recovery of lotic periphyton communities after disturbance. Environ. Manag. 14 589-604.

STEVENSON J (1990) Benthic algal community dynamics in a stream during and after a spate R. J. N. Am. Benth. Soc. 9 277-288.

TAYLOR JC, DE LA REY PA and VAN RENSBURG L (2005c) Recommendations for the collection, preparation and enumeration of diatoms from riverine habitats for water quality monitoring in South Africa. Afr. J. Aquat. Sci. 30 65-75.

TAYLOR JC, HARDING WR, ARCHIBALD CGM, VAN RENSBURG $\mathrm{L}$ (2005b) Diatoms as indicators of water quality in the JukskeiCrocodile river system in 1956 and 1957, a re-analysis of diatom count data generated by BJ Cholnoky. Water SA 31 237-247.

TAYLOR JC, HARDING WR and ARCHIBALD CGM (2005a) A Methods Manual for the Collection, Preparation and Analysis of Diatom Samples. Version 1.0. WRC Report No. TT 281/07. Water Research Commission, Pretoria.

TAYLOR JC, HARDING WR, ARCHIBALD CGM (2007) An Illustrated Guide to some Common Diatom Species from South Africa. WRC Report No. TT 282/07. Water Research Commission, Pretoria.

TER BRAAK CJF (2002) CANOCO version 4.5. Biometrics - quantitative methods in the life and earth sciences. Plant Research International, Wageningen University and Research Centre, Wageningen.

TER BRAAK CJF and SMMILAUER P (2002) CANOCO reference manual and CanoDraw for Windows user's guide: Software for Canonical Community Ordination (version 4.5). Microcomputer Power, Ithaca, NY

VANNOTE RL, MINSHALL GW, CUMMINS KW, SEDELL JR, CUSHING CE (1980) The river continuum concept. Can. J. Fish. Aquat. Sci. 37 130-137.

WEHR JD and SHEATH RG (2003) Freshwater Algae of North America: Ecology and Classification. Academic Press, San Diego.

WHITFIELD AK, PATERSON AW, BOK AH and KOK HM (1994) A comparison of the ichthyofaunas in two permanently open Eastern Cape estuaries. S. Afr. J. Zool. 29 175-185.

WOJTAL AZ and SOBCZYK $€$ (2012) The influence of substrates and physicochemical factors on the composition of diatom assemblages in karst springs and their applicability in water-quality assessment. Hydrobiologia 695 97-108.

WU N, SCHMALZ B and FOHRER N (2011) Distribution of phytoplankton in a German lowland river in relation to environmental factors. J. Plankton Res. 33 807-820. 
http://dx.doi.org/10.4314/wsa.v40i3.10 Available on website http://www.wrc.org.za

ISSN 0378-4738 (Print) $=$ Water SA Vol. 40 No. 3 July 2014 ISSN 1816-7950 (On-line) = Water SA Vol. 40 No. 3 July 2014 